\title{
KEMAMPUAN SISWA BERPIKIR KRITIS MATEMATIKA PADA MATERI KUBUS DAN BALOK DI SMP NEGERI 19 BANDA ACEH
}

\author{
STUDENT ABILITY TO THINK MATH CRITICAL \\ IN CUBE AND BEAM MATERIALS IN SMP NEGERI 19 BANDA ACEH
}

\author{
Khairul Umam ${ }^{1}$, Suryawati ${ }^{2}$ \\ ${ }^{12}$ Department of mathematic Education, Syiah Kuala University
}

E-mail: Khumam77@yahoo.com

Diterima: 12//09/2019; Disetujui: 30/09/2019

\begin{abstract}
ABSTRAK
Berpikir kritis adalah suatu aktivitas mental yang dilakukan untuk mengevaluasi kebenaran sebuah pernyataan. Umumnya evaluasi berakhir dengan putusan untuk menerima, menyangkal, atau meragukan kebenaran pernyataan yang bersangkutan. Kemampuan siswa dalam menyelesaikan permasalahan yang berkenaan dengan matematika masih rendah. Hal tersebut disebabkan karena terbatasnya kemampuan penghafalan konsep atau prosedur untuk menyelesaikan soal sesuai dengan materi yang diberikan. Penelitian ini bertujuan untuk mengetahui kemampuan berpikir kritis matematika siswa pada materi kubus dan balok di kelas VIII SMP Negeri 19 Percontohan Banda Aceh. Pendekatan yang digunakan dalam penelitian ini adalah pendekatan kualitatif. Jenis penelitian ini adalah penelitian deskriptif. Subjek penelitian yaitu kelas VIII-2 yang berjumlah 21 siswa. Sedangkan yang menjadi objek penelitian adalah kemampuan berpikir kritis matematika siswa pada materi kubus dan balok. Pengumpulan data dilakukan dengan cara melakukan tes kemampuan siswa menyelesaikan soal kubus dan balok. Soal yang diberikan berbentuk essay sebanyak 5 soal dan wawancara. Data penelitian bersumber dari hasil tes kemampuan siswa dan wawancara. Berdasarkan hasil penelitian menunjukkan bahwa kemampuan siswa berpikir kritis matematika tergolong tinggi. Hal ini dikarenakan siswa telah memenuhi seluruh tahap berpikir kritis, mulai dari klasifikasi, assessment, inferensi, dan strategi dalam menyelesaikan soal yang diberikan. Siswa pada kelompok ini mengetahui apa saja informasi yang terdapat pada soal, mampu menjelaskan maksud dari soal, dapat menemukan langkah untuk menyelesaikan soal, dan bahkan dapat menemukan cara lain untuk menyelesaikan soal-soal tersebut. Hasil penelitian ini adalah kemampuan siswa berpikir kritis matematika pada materi kubus dan balok di kelas VIII SMP Negeri 19 Percontohan Banda Aceh adalah tinggi. dimana siswa mampu memenuhi keempat indikator berpikir ktitis yaitu klasifikasi, assessment, inferensi, dan strategi.
\end{abstract}

Kata Kunci: Berpikir kritis matematika, kubus dan balok. 


\begin{abstract}
Critical thinking is a mental activity undertaken to evaluate the truth of a statement. Generally the evaluation ends with a decision to accept, deny, or doubt the correctness of the statement in question. The ability of students in solving problems related to math is still low. This is due to the limited ability to memorize the concept or procedure to solve the problem in accordance with the given material. This study aims to determine student's mathematical critical thinking skills on cube and beam material in class VIII SMP Negeri 19 Pilot Banda Aceh. The approach used in this study is a qualitative approach. The type of this research is descriptive research. The research subjects are class VIII-2, which amounts to 21 students. While the object of research is the ability to think critically mathematics students on the material of cubes and beams. Data collection is done by performing student ability test to solve the problem of cube and beam. Problem given essay as much as 5 questions and interviews. The research data is sourced from result of student ability test and interview. Based on the results of research indicates that student's ability to think critically of mathematics is high. This is because students have met all the critical thinking stages, ranging from classification, assessment, inference, and strategy in solving the given problem. Students in this group know what information is contained in the problem, able to explain the purpose of the problem, can find steps to solve the problem, and even can find other ways to solve these problems. The result of this research is student's ability to think critically mathematics on material of cube and beam in class VIII SMP Negeri 19 Banda Aceh Pilot is high. where students are able to meet the four indicators of critical thinking namely classification, assessment, inference, and strategy.
\end{abstract}

Keywords: critical thinking mathematics, cube and beams. 


\section{PENDAHULUAN}

Pendidikan pada dasarnya adalah usaha untuk menumbuh kembangkan potensi daya manusia peserta didik dengan cara mendorong dan memfasilitasi kegiatan belajar mereka. Salah satunya dengan cara mendorong siswa dalam kemampuan berpikir, kemampuan berpikir diperlukan seseorang untuk membantu dirinya dalam menghadapi berbagai perubahan dan tantangan yang terjadi dalam perkembangan ilmu pengetahuan dan teknologi. Selain itu berpikir juga dapat menumbuh kembangkan keaktifan pribadi manusia yang mengakibatkan penemuan yang terarah kepada suatu tujuan (Hasbullah, 2011:5-15).

Menurut Fatmawati, dkk (2014:20) pola berpikir matematika ditinjau dari kedalaman atau kekomplekan terbagi menjadi dua yaitu berpikir tingkat rendah (low-order mathematical thinking) dan berpikir tingkat tinggi (high-order mathematical thinking). Sejalan dengan itu Noer (2009:5) mengungkapkan bahwa kemampuan berpikir kritis sangat diperlukan oleh siswa, karena terkait dengan kebutuhan siswa untuk memecahkan masalah yang dihadapinya dalam kehidupan sehari-hari.

Selain itu Soedjadi (2000:25) menyatakan bahwa kemampuan berpikir kritis sangat diperlukan dalam memecahkan suatu masalah terutama dalam bidang ilmumatematika dimana matematika itu sendiri merupakan "Wahana pendidikan tidak hanya digunakan untuk mencapai suatu tujuan, misalnya mencerdaskan siswa, tetapi dapat pula untuk membentuk kepribadian siswa serta mengembangkan keterampilan tertentu.

$\begin{array}{clr}\text { Selain } & \text { itu Setiawati } & (2011: 596) \\ \text { mengatakan } & \text { sulitnya siswa } & \text { dalam }\end{array}$
menyelesaikan soal pada materi kubus dan balok dimana kesulitan siswa itu yaitu 1) kesulitan memahami soal, siswa tidak menuliskan informasi yang diketahui dalam dan ditanyakan. 2) kesulitan membuat model matematika, siswa menggunakan model yang salah, siswa tidak mampu dalam mengubah kalimat soal ke dalam kalimat matematika. 3) kesulitan menarik kesimpulan, siswa tidak mampu menuliskan kesimpulan sesuai pertanyaan dari soal.

Sehubungan dengan penjelasan tersebut, penulis tertarik untuk melakukan penelitian dengan judul "Analisis Kemampuan Siswa Berpikir Kritis Matematika Pada Materi Kubus dan Balok di Kelas VIII SMP Negeri 19 Percontohan Banda Aceh".

\section{LANDASAN TEORI \\ Pengertian Belajar dan Pembelajaran}

Menurut pengertian secara psikologis, belajar merupakan suatu proses perubahan tingkah laku sebagai hasil dari interaksi dengan lingkungannya dalam memenuhi kebutuhan hidupnya sehingga belajar dapat dikatakan suatu proses usaha yang dilakukan seseorang untuk memperoleh perubahan tingkah laku yang baru secara keseluruhan, sebagai hasil pengalamannya sendiri dalam interaksi dengan lingkungan (Slameto, 1987:28). Disamping itu menurut Anurrahman (2009:13) belajar juga didefenisikan sebagai suatu aktivitas pada diri seseorang yang didasari atau disengaja dan juga interaksi individu dengan lingkungannya. Proses belajar secara kasat mata tidak dapat diamati. Namun demikian, terdapat beberapa indikator pada individu yang dikatakan telah belajar.

Pembelajaran adalah suatu usaha untuk membuat peserta didik belajar atau suatu kegiatan untuk membelajarkan peserta didik. Dengan kata lain, pembelajaran merupakan upaya menciptakan kondisi agar terjadi kegiatan belajar. Dalam hal ini pembelajaran diartikan juga sebagai usaha-usaha yang terencana dalam memanipulasi sumber-sumber belajar agar terjadi proses belajar dalam diri peserta didik (Sardiman, 2006:20). Pembelajaran dapat diartikan juga secara implisit di dalam pembelajaran terdapat kegiatan memilih, menetapkan, dan mengembangkan metode untuk mencapai hasil pembelajaran yang diinginkan. Pembelajaran lebih menekankan pada cara-cara untuk mencapai tujuan dan 
berkaitan dengan cara mengorganisasikan isi pembelajaran, menyampaikan isi pembelajaran dengan mengelola pembelajaran (Sutikno, 2007:47). Pembelajaran mencakup tiga aspek yaitu: peserta didik, proses belajar, dan situasi belajar. Adapun tujuan pembelajaran itu sendiri merupakan hasil belajar bagi siswa setelah melakukan proses belajar dibawah bimbingan guru dalam kondisi yang kondusif.

\section{Kemampuan Berpikir Kritis}

Kemampuan berpikir adalah salah satu cara memecahkan masalah dan menghasilkan sesuatu yang baru. Suatu masalah umumnya tidak dapat dipecahkan tanpa berpikir, dan banyak masalah memerlukan pemecahan yang baru bagi orang-orang atau kelompok. Untuk menghasilkan sesuatu (benda-benda, gagasangagasan) yang baru bagi seseorang, menciptakan sesuatu, itu mencakup pemecahan masalah (Desmita, 2006:20). Di samping itu, berpikir merupakan keadaan berpikir rasional, dapat diukur. Dapat dikembangkan dengan latihan sadar dan sengaja (Munandar, 2009:30). sehingga Tujuan berpikir itu sendiri yaitu untuk menemukan pemahaman atau pengertian yang dikehendaki.

Kemampuan berpikir kritis (critical thinking) adalah salah satu proses mental untuk menganalisis atau mengevaluasi informasi. Umumnya evaluasi berakhir dengan putusan untuk menerima, menyangkal, atau meragukan kebenaran pernyataan yang bersangkutan". Proses berpikir kritis dapat digambarkan seperti metode ilmiah. Sutikno (2007:18) mengutarakan bahwa berpikir kritis adalah metode tentang penyelidikan ilmiah, yaitu: mengidentifikasi masalah, merumuskan hipotesis, mencari dan mengumpulkan data-data yang relevan, menguji hipotesis secara logis dan evaluasi serta membuat kesimpulan yang tepat.

\section{Tinjauan Materi Kubus dan Balok di SMP}

Kubus adalah suatu bangun ruang yang dibatasi oleh enam buah sisi berbentuk persegi yang kongruen (sama besar). Kubus sering disebut bidang enam beraturan atau helisaeder karena dibatasi oleh enam bidang datar yang masing-masing berbentuk persegi yang sama dan sebangun (kongruen). Selain itu terdapat pula unsur-unsur kubus yaitu: sisi/bidang, rusuk, titik sudut, diagonal sisi, diagonal ruang, dan bidang diagonal.

Balok adalah suatu bangun ruang yang dibatasi oleh 6 persegi panjang dimana setiap sisi persegi panjang berimpit dengan tepat satu sisi persegi panjang yang lain dan persegi panjang yang sehadap adalah kongruen. Selain itu terdapat pula unsur-unsur balok yaitu sisi/bidang, rusuk, titik sudut, diagonal sisi, diagonal ruang, dan bidang diagonal.

\section{METODE PENELITIAN}

Sehubungan dengan pendapat di atas kemampuan berpikir matematis peserta didik khususnya pada materi kubus dan balok berkenaan dengan kemampuan untuk menghubungkan persoalan atau informasi yang diperoleh melalui penyelidikan dan pengkajian secara sistematis, sehingga menghasilkan suatu ide atau solusi untuk memecahkan persoalan. Ismaimuza (2013:375) mengatakan salah satu bentuk kemampuan berpikir matematis adalah berpikir kritis, berpikir kritis banyak memberikan manfaat bagi peserta didik, baik dalam pembelajaran matematika maupun dalam kehidupan sehari-hari. Diantaranya dapat meningkatkan dan mengembangkan pemahaman konsep peserta didik sertadapat mengembangkan kemampuan berpikirnya sehingga memudahkan dalam menyelesaikan soal-soal yang lebih kompleks.

\section{Tempat Penelitian}

Peneliti melakukan penelitian disekolah menengah pertama (SMP) Negeri 19 Percontohan Banda Aceh, tepatnya dikelas VIII. Peneliti memilih sekolah tersebut karena merupakan salah satu sekolah percontohan yang ada di Banda Aceh, dimana siswanya banyak yang berprestasi. Siswa-siswa SMP Negeri 19 Percontohan Banda Aceh telah dibiasakan menghadapi soal-soal dalam bentuk berpikir kritis. 


\section{Sumber Data, Intrumen, dan Teknik Pengumpulan Data}

Penelitian ini adalah penelitian kualitatif yang bersifat deskriptif dengan menggunakan metode dan teknik pengumpulan data tertentu sesuai dengan masalah yang akan diteliti. Data yang dikumpulkan dalam penelitian ini adalah data primer yang berupa hasil tes siswa. Untuk memperoleh data tentang kemampuan berpikir kritis matematika, teknik pengumpulan data mengunakan instrumen berupa tes dan wawancara.

Soal tes yang diberikan berbentuk uraian untuk mengungkapkan daya ingat dan pemahaman siswa terhadap materi yang ditanyakan dalam tes dan untuk mengungkapkan kemampuan berpikir kritis siswa melalui jawaban siswa. Adapun langkah penyelesaiannya berdasarkan empat indikator yang meliputi: Strategi, Inferensi, Klarifikasi, Assessment.

\section{Teknik Analisis Data}

Setelah mendapatkan hasil dari tes siswa maka dipilih 6 siswa untuk di wawancarai yang bertujuan untuk mengetahui bagaimana kemampuan berpikir kritis siswa dalam menyelesaikan soal-soal pada materi kubus dan balok. Untuk pemilihan siswa yang akan diwawancarai adalah berdasarkan dari lembar jawaban siswa yang memiliki kemampuan siswa berpikir kritis rendah, kemampuan siswa berpikir kritis sedang dan kemampuan siswa berpikir kritis tinggi. Setelah data terkumpulkan maka dilakukan analisis data sebagai berikut: perhitungan jumlah skor terhadap hasil tes, selanjutnya dilakukan analisis deskriptif yang menyangkut kemampuan berpikir kritis siswa pada materi kubus dan balok serta mendeskripsikan kemampuan berpikir kritis siswa berdasarkan jawaban tes dan hasil wawancara. Jawaban tes dideskripsikan berdasarkan jawaban yang memiliki langkah penyelesaian sesuai dengan empat indikator yang didukung dengan hasil wawancara.

\section{HASIL PENELITIAN DAN PEMBAHASAN}

Pengelompokan tingkat kemampuan berpikir kritis siswa dilakukan sesuai dengan kriteria nilai yang dikemukan oleh Akrikunto (2010:319) dimana siswa yang memcapai nilai 80 ke atas memiliki tinggkat kemampuan berpikir kritis sangat tinggi, siswa yang mencapai nilai 66-79 memiliki tingkat kemampuan berpikir krtis tinggi, siswa yang mencapai nilai antara 56-65 memiliki kemampuan berpikir kritis sedang dan siswa yang memilki nilai 55 kebawah memiliki tingkat kemampuan berpikir kritis rendah

Tabel 1. Tingkat Kemampuan Berpikir Kritis Siswa

\begin{tabular}{|c|c|c|c|c|}
\hline No. & $\begin{array}{c}\text { Persentase } \\
\text { Kemampuan }\end{array}$ & $\begin{array}{c}\text { Kriteria } \\
\text { Kemampuan }\end{array}$ & Banyak Siswa & $\begin{array}{c}\text { Persentase } \\
\text { Jumlah Siswa }\end{array}$ \\
\hline 1. & $66-79$ & Tinggi & 10 & $47,62 \%$ \\
\hline 2. & $56-65$ & Sedang & 6 & $28,57 \%$ \\
\hline 3. & $\leq 55$ & Rendah & 5 & $23,81 \%$ \\
\hline
\end{tabular}

Tabel 1 diatas, menunjukkan bahwa $47,62 \%$ (10 dari 21 orang siswa) yang berkemampuan tinggi, 28,57\% (6 dari 21 orang siswa) yang berkemampuan sedang, dan 23,81\% yaitu (5 dari 21 orang siswa) yang berkemampuan rendah.

Setelah diperoleh nilai siswa berdasarkan tabel 1, maka dipilih 6 siswa untuk diwawancarai. Siswa yang diwawancarai ialah Subjek 1 dan Subjek 10 mewakili siswa dengan kemampuan berpikir kritis tinggi, Subjek 12 dan Subjek 16 mewakili siswa dengan kemampuan berpikir kritis sedang, Subjek 20 dan Subjek 21 mewakili siswa dengan kemapuan berpikir kritis rendah. Hasil Tes Wawancara Siswa Berdasarkan Tingkat Kemampuan Berpikir Kritis Matematika ialah sebagai berikut

Tabel 2. Kemampuan Berpikir Kritis Subjek 1

\begin{tabular}{|c|c|c|c|c|c|}
\hline \multirow{2}{*}{ Tahap } & \multicolumn{5}{|c|}{ Nomor } \\
\cline { 2 - 6 } & 1 & 2 & 3 & 4 & 5 \\
\hline Klarifikasi & $\sqrt{ }$ & $\sqrt{ }$ & $\sqrt{ }$ & $\sqrt{ }$ & $\sqrt{ }$ \\
\hline Assessment & $\sqrt{ }$ & $\sqrt{ }$ & $\sqrt{ }$ & $\sqrt{ }$ & $\sqrt{ }$ \\
\hline Inferensi & - & $\sqrt{ }$ & - & $\sqrt{ }$ & $\sqrt{ }$ \\
\hline Strategi & - & $\sqrt{ }$ & - & $\sqrt{ }$ & - \\
\hline
\end{tabular}

- Tahap Klarifikasi

Siswa (subjek 1) melalui tahap klarifikasi, yaitu siswa dapat menyebutkan informasi yang diketahui dan pernyataan yang diminta dari soal dengan tepat. Siswa bisa melalui tahap klarifikasi untuk setiap nomor soal yang diberikan.

- Tahap Assessment 
Siswa (subjek 1) melalui tahap assessment, yaitu siswa dapat memilih informasi dari soal yang dibutuhkan untuk menyelesaikan soal dan siswa menjelaskan konsep yang akan digunakan untuk menyelesaikan soal dengan menggunakan kata-katanya sendiri. Siswa bisa melalui tahap klarifikasi untuk setiap nomor soal yang diberikan.

\section{- Tahap Inferensi}

Siswa (subjek 1) melalui tahap inferensi, yaitu siswa dapat menggunakan informasi-informasi yang relevan dalam soal dan atau pengetahuan sebelumnya yang ia peroleh untuk menyelesaikan soal serta siswa dapat menjelaskan bagaimana hubungan tiap informasi yang ada. Siswa mampu melalui tahap inferensi pada soal nomor 2, 4, dan 5 .

\section{- Tahap Strategi}

Siswa (subjek 1) melalui tahap strategi, yaitu siswa dapat menemukan langkah lain untuk menyelesaikan soal. Siswa hanya mampu melalui tahap strategi pada soal nomor 2 dan 4 saja.

Tabel 3. Kemampuan Berpikir Kritis Subjek 10

\begin{tabular}{|c|c|c|c|c|c|}
\hline \multirow{2}{*}{ Tahap } & \multicolumn{7}{|c|}{ Nomor } \\
\cline { 2 - 6 } & 1 & 2 & 3 & 4 & 5 \\
\hline Klarifikasi & $\sqrt{ }$ & $\sqrt{ }$ & $\sqrt{ }$ & $\sqrt{ }$ & $\sqrt{ }$ \\
\hline Assessment & $\sqrt{ }$ & $\sqrt{ }$ & $\sqrt{ }$ & $\sqrt{ }$ & $\sqrt{ }$ \\
\hline Inferensi & $\sqrt{ }$ & - & $\sqrt{ }$ & $\sqrt{ }$ & $\sqrt{ }$ \\
\hline Strategi & $\sqrt{ }$ & - & $\sqrt{ }$ & $\sqrt{ }$ & $\sqrt{ }$ \\
\hline
\end{tabular}

- Tahap Klarifikasi

Siswa (subjek 10) melalui tahap klarifikasi, yaitu siswa dapat menyebutkan informasi yang diketahui dan pernyataan yang diminta dari soal dengan tepat. Siswa bisa melalui tahap klarifikasi untuk setiap nomor soal yang diberikan.

\section{- Tahap Assessment}

Siswa (subjek 10) melalui tahap assessment, yaitu siswa dapat memilih informasi dari soal yang dibutuhkan untuk menyelesaikan soal dan siswa menjelaskan konsep yang akan digunakan untuk menyelesaikan soal dengan menggunakan kata -katanya sendiri. Siswa bisa melalui tahap klarifikasi untuk setiap nomor soal yang diberikan.

- Tahap Inferensi
Siswa (subjek 10) melalui tahap inferensi, yaitu siswa dapat menggunakan informasi-informasi yang relevan dalam soal dan atau pengetahuan sebelumnya yang ia peroleh untuk menyelesaikan soal, siswa dapat menjelaskan bagaimana hubungan tiap informasi yang ada. Siswa mampu melalui tahap inferensi kecuali pada soal nomor 2 .

- Tahap Strategi

Siswa (subjek 10) melalui tahap strategi, yaitu siswa dapat menemukan langkah lain untuk menyelesaikan soal. Siswa mampu melalui tahap strategi kecuali pada soal nomor 2 .

\section{Tabel 4. Kemampuan Berpikir Kritis Subjek} 12

\begin{tabular}{|c|c|c|c|c|c|}
\hline \multirow{2}{*}{ Tahap } & \multicolumn{5}{|c|}{ Nomor } \\
\cline { 2 - 6 } & 1 & 2 & 3 & 4 & 5 \\
\hline Klarifikasi & $\sqrt{ }$ & $\sqrt{ }$ & $\sqrt{ }$ & $\sqrt{ }$ & $\sqrt{ }$ \\
\hline Assessment & $\sqrt{ }$ & $\sqrt{ }$ & $\sqrt{ }$ & $\sqrt{ }$ & $\sqrt{ }$ \\
\hline Inferensi & $\sqrt{ }$ & - & - & $\sqrt{ }$ & $\sqrt{ }$ \\
\hline Strategi & - & - & - & $\sqrt{ }$ & - \\
\hline
\end{tabular}

- Tahap Klarifikasi

Siswa (subjek 12) melalui tahap klarifikasi, yaitu siswa dapat menyebutkan informasi yang diketahui dan pernyataan yang diminta dari soal dengan tepat. Siswa bisa melalui tahap klarifikasi untuk setiap nomor soal yang diberikan.

- Tahap Assessment

Siswa (subjek 12) melalui tahap assessment, yaitu siswa dapat memilih informasi dari soal yang dibutuhkan untuk menyelesaikan soal dan siswa menjelaskan konsep yang akan digunakan untuk menyelesaikan soal dengan menggunakan kata -katanya sendiri. Siswa bisa melalui tahap klarifikasi untuk setiap nomor soal yang diberikan.

- Tahap Inferensi

Siswa (subjek 12) melalui tahap inferensi, yaitu siswa dapat menggunakan informasi-informasi yang relevan dalam soal dan atau pengetahuan sebelumnya yang ia peroleh untuk menyelesaikan soal, siswa dapat menjelaskan bagaimana hubungan tiap informasi yang ada. Siswa mampu melalui tahap inferensi pada soal nomor 1, 4, dan 5 .

- Tahap Strategi 
Siswa (subjek 12) melalui tahap strategi, yaitu siswa dapat menemukan langkah lain untuk menyelesaikan soal. Siswa hanya mampu melalui tahap strategi pada soal nomor 4 saja.

Tabel 5. Kemampuan Berpikir Kritis Subjek 16

\begin{tabular}{|c|c|c|c|c|c|}
\hline \multirow{2}{*}{ Tahap } & \multicolumn{5}{|c|}{ Nomor } \\
\cline { 2 - 6 } & 1 & 2 & 3 & 4 & 5 \\
\hline Klarifikasi & $\sqrt{ }$ & $\sqrt{ }$ & $\sqrt{ }$ & $\sqrt{ }$ & $\sqrt{ }$ \\
\hline Assessment & $\sqrt{ }$ & $\sqrt{ }$ & $\sqrt{ }$ & $\sqrt{ }$ & $\sqrt{ }$ \\
\hline Inferensi & $\sqrt{ }$ & $\sqrt{ }$ & - & $\sqrt{ }$ & $\sqrt{ }$ \\
\hline Strategi & - & - & - & - & - \\
\hline
\end{tabular}

\section{- Tahap Klarifikasi}

Siswa (subjek 16) melalui tahap klarifikasi, yaitu siswa dapat menyebutkan informasi yang diketahui dan pernyataan yang diminta dari soal dengan tepat. Siswa bisa melalui tahap klarifikasi untuk setiap nomor soal yang diberikan.

\section{- Tahap Assessment}

Siswa (subjek 16) melalui tahap assessment, yaitu siswa dapat memilih informasi dari soal yang dibutuhkan untuk menyelesaikan soal dan siswa menjelaskan konsep yang akan digunakan untuk menyelesaikan soal dengan menggunakan kata -katanya sendiri. Siswa bisa melalui tahap klarifikasi untuk setiap nomor soal yang diberikan.

\section{- Tahap Inferensi}

Siswa (subjek 16) melalui tahap inferensi, yaitu siswa dapat menggunakan informasi-informasi yang relevan dalam soal dan atau pengetahuan sebelumnya yang ia peroleh untuk menyelesaikan soal, siswa dapat menjelaskan bagaimana hubungan tiap informasi yang ada. Siswa mampu melalui tahap inferensi kecuali pada soal nomor 3.

- Tahap Strategi

Siswa (subjek 16) tidak melalui tahap strategi.

Tabel 6. Tabel Kemampuan Berpikir Kritis Subjek 20

\begin{tabular}{|c|c|c|c|c|c|}
\hline \multirow{2}{*}{ Tahap } & \multicolumn{5}{|c|}{ Nomor } \\
\cline { 2 - 6 } & 1 & 2 & 3 & 4 & 5 \\
\hline Klarifikasi & $\sqrt{ }$ & $\sqrt{ }$ & $\sqrt{ }$ & $\sqrt{ }$ & $\sqrt{ }$ \\
\hline Assessment & $\sqrt{ }$ & - & - & - & - \\
\hline Inferensi & $\sqrt{ }$ & - & - & - & - \\
\hline Strategi & - & - & - & - & - \\
\hline
\end{tabular}

- Tahap Klarifikasi
Siswa (subjek 20) melalui tahap klarifikasi, siswa dapat menyebutkan informasi yang diketahui dan pernyataan yang diminta dari soal dengan tepat. Siswa bisa melalui tahap klarifikasi untuk setiap nomor soal yang diberikan.

\section{- Tahap Assessment}

Siswa (subjek 20) melalui tahap assessment, yaitu siswa dapat memilih informasi dari soal yang dibutuhkan untuk menyelesaikan soal dan siswa menjelaskan konsep yang akan digunakan untuk menyelesaikan soal dengan menggunakan kata -katanya sendiri. Siswa bisa melalui tahap klarifikasi untuk setiap nomor soal yang diberikan.

\section{- Tahap Inferensi}

Siswa (subjek 20) melalui tahap inferensi, yaitu siswa dapat menggunakan informasi-informasi yang relevan dalam soal dan atau pengetahuan sebelumnya yang ia peroleh untuk menyelesaikan soal, siswa dapat menjelaskan bagaimana hubungan tiap informasi yang ada. Siswa mampu melalui tahap inferensi hanya pada soal nomor 1 .

- Tahap Strategi

Siswa (subjek 20) tidak melalui tahap strategi.

\section{Tabel 7. Kemampuan Berpikir Kritis Subjek} 21

\begin{tabular}{|c|c|c|c|c|c|}
\hline \multirow{2}{*}{ Tahap } & \multicolumn{5}{|c|}{ Nomor } \\
\cline { 2 - 6 } & 1 & 2 & 3 & 4 & 5 \\
\hline Klarifikasi & $\sqrt{ }$ & - & $\sqrt{ }$ & $\sqrt{ }$ & $\sqrt{ }$ \\
\hline Assessment & - & - & - & $\sqrt{ }$ & $\sqrt{ }$ \\
\hline Inferensi & - & - & - & $\sqrt{ }$ & $\sqrt{ }$ \\
\hline Strategi & - & - & - & $\sqrt{ }$ & - \\
\hline
\end{tabular}

- Tahap Klarifikasi

Siswa (subjek 21) melalui tahap klarifikasi, yaitu siswa dapat menyebutkan informasi yang diketahui dan pernyataan yang diminta dari soal dengan tepat. Siswa bisa melalui tahap klarifikasi kecuali pada soal nomor 2.

- Tahap Assessment

Siswa (subjek 21) melalui tahap assessment, yaitu siswa dapat memilih informasi dari soal yang dibutuhkan untuk menyelesaikan soal dan siswa menjelaskan konsep yang akan digunakan untuk menyelesaikan soal dengan menggunakan kata -katanya sendiri. Siswa bisa melalui tahap klarifikasi kecuali pada soal nomor 2 . 


\section{- Tahap Inferensi}

Siswa (subjek 21) melalui tahap inferensi, yaitu siswa dapat menggunakan informasi-informasi yang relevan dalam soal dan atau pengetahuan sebelumnya yang ia peroleh untuk menyelesaikan soal, siswa dapat menjelaskan bagaimana hubungan tiap informasi yang ada. Siswa mampu melalui tahap inferensi pada soal nomor 4, dan 5.

- Tahap Strategi

Siswa (subjek 1) melalui tahap strategi, yaitu siswa dapat menemukan langkah lain untuk menyelesaikan soal. Siswa hanya mampu melalui tahap strategi pada soal nomor 4 saja.

\section{PEMBAHASAN}

Data yang diperoleh melalui tes mengenai tingkat kemampuan berpikir kritis siswa terdapat 10 siswa dengan kemampuan berpikir kritis tinggi, 6 siswa berkemampuan berpikir kritis sedang, dan 5 siswa memiliki kemampuan berpikir kritis rendah.

Berdasarkan data yang diperoleh melalui wawancara mengenai proses berpikir kritis siswa dalam menyelesaikan masalah yang diberikan pada materi kubus dan balok, siswa pada kelompok tingkat kemampuan berpikir kritis tinggi diwakili oleh subjek 1 (S-1) dan subjek 10 (S-10). Siswa S-1 melalui tahap berpikir kritis klarifikasi dan assessment pada soal nomor 1,2, 3, 4, dan 5. Siswa melalui tahap inferensi pada soal nomor 2, 4, dan 5, ini dikarenakan siswa bingung dalam menentukan cara menyelesaikan soal nomor 1 dan 3 . Sedangkan tahap strategi pada soal nomor 2 dan 4, hal ini diakibatkan oleh siswa kurang memahami cara atau alternatif lain yang bisa digunakan untuk menyelesaikan soal. Sedangkan siswa S-10 melalui tahap berpikir kritis klarifikasi dan assessment pada soal nomor $1,2,3,4$, dan 5, tahap inferensi dan stategi pada soal 1, 3, 4, dan 5, hal ini dikarenakan siswa kurang memahami soal nomor 2 .

Pada kelompok tingkat kemampuan berpikir kritis sedang diwakili oleh subjek 12 (S-12) dan subjek 16 (S-16). Siswa S-12 melalui tahap berpikir kritis klarifikasi dan assessment pada soal nomor 1,2, 3, 4, dan 5. Siswa melalui tahap inferensi pada soal nomor 1, 4, dan 5, ini dikarenakan siswa tidak mengerti cara untuk menyelesaikan soal nomor 2 dan 3. Sedangkan tahap strategi hanya pada soal nomor 4. Sedangkan siswa S-16 melalui tahap berpikir kritis klarifikasi dan assessment pada soal nomor 1,2, 3, 4, dan 5. Siswa melalui tahap inferensi pada soal nomor 1, 2, 3, dan 5, sedangkan untuk tahap strategi tidak satu soal pun dilalui oleh siswa.

Kelompok lainnya ialah kelompok tingkat kemampuan berpikir kritis rendah diwakili oleh subjek 20 (S-20) dan subjek 21 (S21). Untuk tahap klarifikasi siswa S-20 mampu melalui di semua nomor soal, tahap assessment tidak dilalui hanya pada soal nomor 3. Pada soal nomor 3 S-20 hanya menegtahui informasi yang terdapat pada soal. Untuk tahap inferensi hanya dilalui pada soal nomor 1, namun ia tidak melalui tahap strategi. Sedangkan siswa S-21 melalui tahap berpikir kritis klarifikasi dan assessment pada soal nomor 1,2, 4, dan 5. S-21 tidak melalui tahap apa pun pada soal nomor 3 , ia melalui tahap inferensi pada soal nomor 4 dan 5, dan tahap strategi pada soal nomor 4.

Berdasarkan dta nilai tes dan hasil wawancara siswa yang telah dianalisis, proses berpikir kritis siswa kelas VIII SMP Negeri 19 Percontohan Banda Aceh dapat diklasifikasikan sebagai berikut:

Siswa pada kelompok dengan tingkat kemampuan berpikir kritis tinggi yang diwakili oleh S-1 dan S-10 cenderung memenuhi atau melalui seluruh tahap berpikir kritis, mulai dari klasifikasi, assessmet, inferensi, dan strategi dalam menyelesaikan soal yang diberikan. Siswa pada kelompok ini mengetahui apa saja informasi yang terdapat pada soal, mampu menjelaskan maksud dari soal, dapat menemukan langkah untuk menyelesaikan soal, dan bahkan dapat menemukan cara lain untuk menyelesaikan soal-soal tersebut.

Pada kelompok dengan tingkat kemampuan berpikir kritis sedang yang diwakili oleh S-12 dan S-16 siswa hampir memenuhi seluruh tahap berpikir kritis, namun siswa kesulitan atau melawatkan tahap strategi. Siswa bisa melalui tahap klasifikasi, assessmet, inferensi. Dimana siswa mampu menjelaskan 
informasi yang dikatahui dari soal, pertanyaan yang teerdapat pada soal, dan menentukan langkah dalam menyelesaikan soal, meskipun dalam beberapa nomor siswa masih keliru dalam menentukan langkah untuk menyelesaikan soal.

Sedangkan siswa pada kelompok dengan tingkat kemampuan berpikir kritis rendah yang diwakili oleh S-20 dan S-21 hanya mampu melalui tahap berpikir kritis klasifikasi dan assessment. Siswa nyaris tidak melalui tahap strategi, sedangkan untuk tahap inferensi S-21 mampu melalui di soal nomor 4 dan 4 saja. Siswa pada kelompok ini bahkan ada yang tidak menjawab sama sekali soal yang diberikan. Secara umum siswa dengan tingkat kemampuan berpikir kritis rendah hanya mampu menjelaskan apa yang diketahui dalam soal, apa yang ditanyakan dalam soal, namun kebingungan dalam menentukan lankah yang akan digunakan dalam menyelesaikan soal.

Dari hasil penelitian yang telah dilakukan sebelumnya oleh Setiawan (2012:51) bahwa kemampuan berpikir kritis siswa pada SMPN 1 Turi Lamongan Jawa Timur memiliki kemampuan berpikir kritis tinggi. Hal ini disebabkan pada penyelesaian soal-soal pada materi kubus dan balok siswa telah melalui tahap strategi dan klasifikasi.

Berdasarkan analisis data yang telah dilakukan dapat dikatakan bahwa siswa kelas VIII SMP Negeri 19 Percontohan Banda Aceh siswa sudah memahami materi yang diuji pada saat tes berlangsung. Dimana siswa sudah melalui berbagai tahap yaitu: klarifikasi, assessment, inferensi, dan strategi. Dari 21 siswa, sebanyak 10 siswa $(47,62 \%)$ sudah mampu memahami maksud dari soal yang diberikan serta mampu melalui setiap tahap berpikir kritis. Namun hanya 5 siswa $(23,81 \%)$ yang tidak melalui tahap inferensi dan strategi pada penyelesaian soal-soal yang diberikan. Dengan demikian, tingkat kemampuan berpikir kritis siswa kelas VIII SMP Negeri 19 Percontohan Banda Aceh dapat digolongkan dalam kategori tinggi.

\section{KESIMPULAN}

Berdasarkan hasil penelitian dapat disimpulkan bahwa hasil tes terhadap 5 soal yang diberikan kepada 21 orang siswa dan dipilih hanya 6 orang siswa yang menjadi subjek wawancara, maka $47,62 \%$ (10 orang siswa) yang memiliki tingkat kemampuan berpikir kritisnya tinggi, 28,57\% (6 orang siswa) diantaranya memiliki tingkat kemampuan sedang dan $23,81 \%$ (5 siswa) memiliki tingkat kemampuan rendah. Maka dari itu dapat dikatakan bahwa kemampuan siswa berpikir kritis matematika pada materi kubus dan balok di kelas VIII SMP Negeri 19 Percontohan Banda Aceh adalah tinggi, dimana siswa mampu memenuhi tahap berpikir ktitis yaitu klasifikasi, assessmet, inferensi, dan strategi.

Salah satu upaya yang dapat dilakukan untuk meningkatkan kemampuan berpikir kritis siswa adalah hendaknya siswa membiasakan diri untuk berpikir kritis, kreatif dalam memecahkan masalah serta membiasakan untuk memahami setiap materi yang diajarkan. Dalam meningkatkan penguasaan siswa terhadap materi kubus dan balok, hendaknya guru memberikan penekanan pada konsep-konsep dasar kepada siswa. Kepada peneliti berikutnya agar dapat memperluas lagi tentang kemampuan siswa berpikir kritis matematika terhadap materi yang lain. 


\section{DAFTAR PUSTAKA}

Anurrahman. 2009. Belajar dan Pembelajaran. Bandung: Alfabeta

Arikunto, Suharsimi. (2010). Prosedur Penelitian Suatu Pendekatan Praktik. Edisi revisi. Jakarta: Rineka Cipta.

Desmita. (2006). Psikologi Perkembangan. Bandung: PT. Remaja Rosdakarya.

Fatmawati, Harlinda, dkk. (2014). Analisis Berpikir Kritis Siswa dalam Memecahkan Masalah Matematika Berdasarkan Polya Pada Pokok Bahasan Persamaan Kuadrat. Jurnal Elektronik Pendidikan Matematika. Vol: 2. No.9. Hal: 899-910.

Hasbullah. (2011). Dasar-dasar Ilmu Pendidikan. Jakarta: PT Raja Grafindo. Persada.

Ismaimuza, Dasa dan Selvy Musdalifah. (2013). Pengembangan Kemampuan Berpikir Kritis Matematis Untuk siswa SMP.

Munandar, Utami. (2009). Kreatifitas Pengembangan Anak Berbakat. Jakarta: Rineka Cipta.

Sardiman. 2006. Interaksi dan Motivasi Belajar Mengajar. Jakarta: PT Raja Grafindo Persada.

Setiawan, Yusuf. 2012. Analisis Proses Berpikir Kritis Siswa Dalam Memecahkan Masalah TerbukaPada Materi Kubus dan Balok di Kelas VIII SMP Negeri 1 Turi Lamongan. Tesis. Surabaya: UIN Sunan Ampel Surabaya.

Setiawati. (2011). Kesulitan Belajar Siswa. Yogyakarta: Graha Ilmu.

Slameto. 1987. Belajar dan Faktor-Faktor yang Mempengaruhinya. Jakarta: Cipta

Soedjadi, R. (2000). Kiat-Kiat Pendidikan Matematika Di Indonesia. Jakarta: direktorat jendral pendidikan.

Sutikno, M. Sabry. (2007). Menggagas Pembelajaran Efektif dan Bermakna. Mataram:NTP Press. 